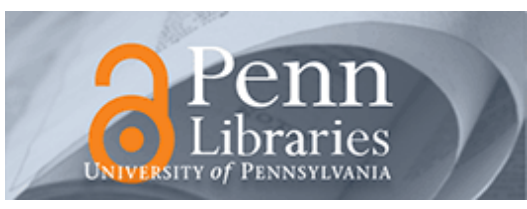

University of Pennsylvania ScholarlyCommons

Wharton Pension Research Council Working

Papers

Wharton Pension Research Council

$1-1-2008$

\title{
Footnotes Aren't Enough: The Impact of Pension Accounting on Stock Values
}

Julia Coronado

Barclay's Capital, julia.coronado@barcap.com

Steven A. Sharpe

Federal Reserve Board, steve.a.sharpe@frb.gov

Olivia S. Mitchell

The Wharton School, University of Pennsylvania, mitchelo@wharton.upenn.edu

S. Blake Nesbitt

The Wharton School, University of Pennsylvania, blake.nesbitt@gmail.com

Follow this and additional works at: https://repository.upenn.edu/prc_papers

Part of the Economics Commons

Coronado, Julia; Sharpe, Steven A.; Mitchell, Olivia S.; and Nesbitt, S. Blake, "Footnotes Aren't Enough: The Impact of Pension Accounting on Stock Values" (2008). Wharton Pension Research Council Working Papers. 293.

https://repository.upenn.edu/prc_papers/293

This paper is posted at ScholarlyCommons. https://repository.upenn.edu/prc_papers/293

For more information, please contact repository@pobox.upenn.edu. 


\title{
Footnotes Aren't Enough: The Impact of Pension Accounting on Stock Values
}

\begin{abstract}
Some research has suggested that companies with defined benefit (DB) pensions are sometimes significantly misvalued by the market. This is because the measures of pension cost and pension net liabilities embedded in financial statements, taken at face value, can provide very misleading picture of pension finances. The more pertinent information on pension finances is relegated to footnotes, but might not receive much attention from portfolio managers. But dramatic swings in the financial conditions of large DB plans around the turn of the decade focused widespread attention on pension accounting practices, and dissatisfaction with current accounting standards has recently prompted the Financial Accounting Standards Board (FASB) to take up a project revamp DB pension accounting. Arguably, the increased attention should have made investors wise to the informational problems, thereby eliminating systematic mispricing in recent years. We test this proposition and conclude that investors continued to misvalue DB pensions, inducing sizable valuation errors in the stock of many companies. Our findings suggest that FASB's current reform efforts could substantially aid the market's ability to value firms with DB pensions.
\end{abstract}

\section{Disciplines}

Economics 


\title{
Footnotes Aren't Enough: The Impact of Pension Accounting on Stock Values
}

\author{
Julia Coronado, Olivia S. Mitchell, Steven A. Sharpe, and S. Blake Nesbitt
}

January 2008

\author{
PRC WP2008-03 \\ Pension Research Council Working Paper \\ Pension Research Council \\ The Wharton School, University of Pennsylvania \\ 3620 Locust Walk, 3000 SH-DH \\ Philadelphia, PA 19104-6302
}

Tel: 215.898.7620 Fax: 215.573.3418

Email: prc@wharton.upenn.edu

http://www.pensionresearchcouncil.org

This research was conducted with support from Barclays Capital, The Federal Reserve Board, and the Pension Research Council (PRC) at the Wharton School of the University of Pennsylvania. The authors are grateful for data provided by Wharton Data Research Services and useful suggestions from Daniel Covitz. Opinions and errors are solely those of the authors, and not of the institutions with whom the authors are affiliated. (C) 2008 Coronado, Sharpe, Mitchell, and Nesbitt. All rights reserved. All findings, interpretations, and conclusions of this paper represent the views of the author(s) and not those of the Wharton School or the Pension Research Council. (C) 2008 Pension Research Council of the Wharton School of the University of Pennsylvania. All rights reserved. 


\title{
Footnotes Aren't Enough: The Impact of Pension Accounting on Stock Values
}

\author{
Julia Coronado, Olivia S. Mitchell, Steven A. Sharpe, and S. Blake Nesbitt
}

\begin{abstract}
$\underline{\text { Abstract }}$
Some research has suggested that companies with defined benefit (DB) pensions are sometimes significantly misvalued by the market. This is because the measures of pension cost and pension net liabilities embedded in financial statements, taken at face value, can provide very misleading picture of pension finances. The more pertinent information on pension finances is relegated to footnotes, but might not receive much attention from portfolio managers. But dramatic swings in the financial conditions of large DB plans around the turn of the decade focused widespread attention on pension accounting practices, and dissatisfaction with current accounting standards has recently prompted the Financial Accounting Standards Board (FASB) to take up a project revamp DB pension accounting. Arguably, the increased attention should have made investors wise to the informational problems, thereby eliminating systematic mispricing in recent years. We test this proposition and conclude that investors continued to misvalue DB pensions, inducing sizable valuation errors in the stock of many companies. Our findings suggest that FASB's current reform efforts could substantially aid the market's ability to value firms with DB pensions.

Julia Coronado

Barclays Capital

200 Park Ave

New York, NY 10166

Phone: 212.412.1476

Email: Julia.coronado@barcap.com

Steven A. Sharpe (corresponding author)

Division of Research and Statistics, Federal Reserve Board,

20th and C Streets, NW

Washington, DC 20551

Phone: 202.452.2875

Email: ssharpe@frb.gov

Olivia S. Mitchell

Pension Research Council, Dept of Insurance/Risk Management

The Wharton School, University of Pennsylvania

3000 SH-DH, 3620 Locust Walk

Philadelphia, PA 19104-6218

Phone: 215.746.5701

Fax: 215.898.0310

E-mail: mitchelo@wharton.upenn.edu

S. Blake Nesbitt

Pension Research Council

The Wharton School, University of Pennsylvania

3000 SH-DH, 3620 Locust Walk

Philadelphia, PA 19104-6218

Phone: 310.486 .4871

Email: blake.nesbitt@gmail.com
\end{abstract}




\section{Footnotes Aren't Enough: The Impact of Pension Accounting on Stock Values}

About two-thirds of large US companies provide employees with a traditional defined benefit (DB) pension which pays retiree benefits in the form of a life annuity. These annuities are financed by corporate contributions to a separately-managed pension fund invested under the aegis of the plan sponsor. By law, the sponsoring corporation is required to have enough assets on hand to fund, or pay for, all accrued vested benefits, even if the parent company were to go out of business. Yet there is flexibility in the funding rules, and it is often difficult to assess the current health of a corporate pension fund. Determining the plan's funded status requires knowledge of the present discounted value of future benefit flows and the market value of pension assets, yet pension fund finances are reported under rather arcane accounting conventions (McGill et al., 1996). In particular, current accounting and actuarial practice permits smoothing of changes in the values of pension assets and liabilities, making it difficult for investors to readily ascertain the current funded status of a DB plan.

If defined benefit pension accounting is, in fact, "opaque", this can make it difficult to properly value firms that sponsor DB plans (Gold, 2005). While the market values of pension assets and liabilities are disclosed in the footnotes to annual financial statements, considerable expertise may be required to evaluate the value-relevance of the pension-related accruals embedded in the income statement. For instance, in the latter half of the 1990s, many corporate DB plans became significantly overfunded and the earnings on pension fund investments significantly boosted the reported profitability of the sponsoring corporations. Some market analysts argued that this produced a misleading picture of the sponsors' core business 
performance. Then between 2000 and 2002, when the stock market plunged, interest rates fell, and the net position of most DB plans took a 180-degree turn. The effects on the sponsor financial statements - particularly their profitability - showed up only with a substantial lag.

This paper evaluates whether investors can see through the financial statement, so as to value corporate sponsor DB pension funding status based on economic values of pension assets and obligations. In particular, we test the transparent view of pension valuation, against a specific alternative hypotheses in which firm equity value instead naively reflects the pension accruals located on the income statement, and thus fails to accurately reflect the economic value of net pension assets. In doing so, we extend the work of Coronado and Sharpe (2003) to a period when the distortions to accounting statements were glaring enough to capture the attention of many market analysts and policymakers, and we assess whether increased scrutiny has brought about more accurate pension valuation. Our results thus allow us to comment on the likely impact of new Financial Accounting Standards Board (FASB) statements seeking to incorporate more value-relevant information on current pension values in financial statements.

Despite huge swings in pension valuations and heightened attention devoted to pension funding, we show that equity prices of firms sponsoring DB plans still fail to reflect the true economic value of pension assets and liabilities. Instead, we conclude that firm valuations continue to be unduly influenced by the accruals reported in firm income statements, while placing little or no weight on the incremental information in the fair value of the net pension position reported in the footnotes to annual financial statements. The implication is that proposed changes to accounting standards will likely have an impact on the market values of pension sponsors. 


\section{Prior Analysis and Regulatory Trends}

An economic view of DB pension fund valuation takes the perspective of a consolidated corporate balance sheet. Here, pension assets and liabilities are assumed to be marked-to-market by investors, and thus contribute to firm value dollar-for-dollar (or somewhat less once tax effects are considered). ${ }^{1}$ During the late 1970 s, the prevalence of underfunded DB plans spurred several empirical studies aimed at estimating the impact of DB pension plans on firm valuation. Many of these concluded that the market did, in fact, value net DB liabilities in a manner consistent with the consolidated balance sheet - in accordance with the "transparent" hypothesis. $^{2}$

Despite these findings, many market participants at the time suspected that the unfavorable financial position of most DB pensions was not fully reflected in share prices. In particular, the financial community worried that the value of plan assets and liabilities was measured inconsistently across firms and inadequately disclosed, making it difficult for investors to accurately determine the impact of DB pensions on firm value. Firms were required to disclose their net pension assets, but they were not required to do so within their financial statements. ${ }^{3}$ Indeed, the only manifestation of such plans on corporate financial statements was the annual cash contributions to these plans, which flowed through as an expense on the income statement. Furthermore, a variety of actuarial methods and assumptions were used to determine the market value of liabilities.

To address these concerns, the Financial Accounting Standards Board (FASB 1985)

\footnotetext{
${ }^{1}$ Since these plans enjoy special tax treatment, net pension assets or liabilities should reflect after-tax dollars; and since the federal government partially insures these benefits, risky firms actually preserve a "put option" on the government suggesting that the pension liabilities will be valued less than dollar-for-dollar. See Black (1980), Feldstein and Seligman (1981), and Tepper (1981) for a discussion of taxes and Sharpe (1976) for an analysis of the impact of pension insurance.

2 These papers include Feldstein and Seligman (1981), Feldstein and Morck (1983), and Bulow, Morck, and Summers (1987).

${ }^{3}$ See McGill, et al. (1996) for a more complete description of the evolution of pension accounting.
} 
issued Statement Number 87, Employers' Accounting for Pensions, stipulating a new accounting approach to be employed in fiscal years beginning after December 15, 1986. Broadly speaking, FAS 87 standardized actuarial assumptions for valuing pension liabilities and set forth a new method for measuring pension expense on the income statements of sponsoring firms. Rather than booking the actual cash contributions, companies now had to calculate pension expense using a complicated accrual methodology in which the cost of new benefits are offset by an expectation of average long-run returns on pension assets. These guidelines also required disclosure of the fair market value of pension assets and liabilities within the footnotes to the annual financial statements, although the plan's current funding position was still not reflected on the corporate balance sheet. ${ }^{4}$

The FAS 87 efforts to boost standardization and improve measurement and disclosure of pension finances on company statements were positive steps, but increasingly they too have come under fire. Analysts are concerned about the potential for conflicting signals from the income statement accruals and marked-to-market pension balance sheet information that FAS 87 has required firms to disclose in footnotes to their annual reports. Critics of pension accounting conventions expressed alarm that the serious funding shortfalls for many DB plans which resulted from the stock market bust at the beginning of the decade are not fully reflected in company financial statements. For instance, Zion and Carcache's (2002) work shows that pension costs reflected in company income statements are a lagging indicator of a pension plan's true funding status. Moreover, the financial community has been particularly vocal about its concerns. As an example, Standard and Poor's introduced a "core earnings" concept which gauges corporate operating earnings after stripping out some of the components of the pension

\footnotetext{
${ }^{4}$ While many of the general principles for setting actuarial assumptions used in the accounting calculations are similar in spirit to those used in DB funding calculations required under ERISA, they are not explicitly linked.
} 
accruals as well as other items (Blitzer, et al., 2001). Several Wall Street firms and prominent investment gurus including Warren Buffet have also called for a fundamental revision to the way pension costs are measured.

Responding to the growing concern over the lack of transparency embedded in FAS 87, the FASB (2003) has continued to reevaluate and revise pension accounting. One set of changes, implemented for financial statements ending after December 15, 2006, required pension sponsors to mark their pension assets and liabilities to market on corporate balance sheets as opposed to using actuarially smoothed values. The second phase, which is to review and revise the measures of pension cost reflected on the income statement, is expected to take two to three additional years to complete and implement.

\section{Pension Accounting and Value Relevancy}

The measure of pension expense reflected in the income statement under the FAS 87 guidelines, net periodic pension cost (NPPC), is calculated as the annual accrued costs of the pension plan minus the expected return on plan assets. As shown in Table 1, two key cost components of the NPPC are service cost and interest cost. Other costs include amortization of previous gains and losses, amortization of prior service cost, and finally some ad hoc items such as charges for plan amendments and changes in actuarial assumptions. The service cost is equal to the present value of the pension benefits earned by employees during the year, in essence, the cost of deferred compensation. The interest cost is calculated as the beginning-of-year value of pension obligations multiplied by the plan's assumed discount rate; this represents the cost of financing the outstanding pension obligation, that is, the increase in the benefit obligation resulting from the passage of time. Under FAS 87 guidelines, the assumed discount rate must 
reflect the rate at which current liabilities could be settled. As a matter of practice, firms often use the Moody's AA rate.

\section{Table 1 here}

The offset to plan costs in the NPPC is the expected return on plan assets, which is calculated as the product of two items: (i) the plan's assumed long-run rate of return, and (ii) the accounting value, or "market-related value", of the plan's assets. The market-related value can be either the fair market value of assets, or a systematically smoothed accounting value whereby unexpected returns are amortized over a period not exceeding five years. Thus, for firms that choose the maximum amortization period - a majority of firms according to Zion and Carcache (2002) - the market-related value would be similar to a five-year moving average of the true market value. Thus, the expected return component of the NPPC in many cases will reflect the actual market value of pension assets only with a substantial lag. ${ }^{5}$

The key assumption for calculating the expected returns component is the assumed longrun rate of return on plan assets, which is generally different from the discount rate used to calculate the present value of liabilities and the current year's interest cost. In choosing the longrun return assumption, FAS 87 guidelines require the firm to consider the return currently being earned on plan assets and rates of return expected in the future. Thus, for accounting purposes, the firm is explicitly directed to use an expected rate of return without regard to the riskiness of the underlying portfolio. ${ }^{6}$

Gold (2005) argued that FAS 87 formalizes a systemic financial bias in pension accounting favoring equity investments. This is because the volatility of actual returns on

\footnotetext{
${ }^{5}$ In addition, changes in liabilities that result from interest rate movements are smoothed into the corporate income statement through the "other cost" component of the NPPC over a number of years.

${ }^{6}$ Most of our sample period is characterized by low long-term interest rates relative to expected equity returns. Indeed, the average assumed long-run rate of return in our sample was around 9 percent, while the average discount rate was closer to 7 percent.
} 
pension plan assets does not show through on the sponsor's financial statements, while the assumed expected return on the plan's portfolio is not adjusted for risk. In choosing the plan's expected long-run rate of return on pension assets, firms anticipate or assume an equity premium. At the same time, because of the smoothing built into net pension cost from using expected returns with amortization, little of the volatility that gives rise to the equity premium shows up on the sponsoring firm's financial statements. Rather, the underlying income volatility (as well as the effective boost to leverage) is revealed only through the disclosure of marked-to-market values for pension assets and obligations in the footnotes to the annual reports.

As a result of this smoothing, it seems plausible that the consolidated balance sheet model - or the "transparent model" - of pension valuation assumed in many analyses may not be accurate. Instead, investors might utilize valuation techniques that rely on earnings and forecasts of earnings, which embed the stream of pension expenses reported on the income statement, while ignoring the marked-to-market value of net pension assets reported in the footnotes. Because the information presented on the income statement contains a downward-biased measure of risk-adjusted pension expense, the opaque model - which assumes investors use information on the financial statements but not in the footnotes - implies that the market will overprice firms that sponsor DB pension plans. ${ }^{7}$

To test the transparent model of valuation we divide the net pension expense (NPPC) into two components, labeled service costs and financing accruals, as shown at the bottom of Table 1. Service cost is the component that measures deferred compensation accrued over the year, which we consider to be a "core" labor expense of the business. The second piece, financing

\footnotetext{
${ }^{7}$ The discrepancy between the assumed rate of return and the discount rate generates a flow of income out of the pension plan operations and onto the income statement of the sponsoring firm. To see this, consider a plan that starts the period fully funded, that is, where the value of assets exactly equals the value of liabilities. The expected return on plan assets, calculated by multiplying the value of plan assets by the assumed return, will more than offset the growth in liabilities, or the interest cost, calculated as the product of the discount rate and the plan's liability.
} 
accruals, contains everything else; however, aside from amortizations of previous plan amendments (which recognizes changes in plan benefits over the term of employees' years of service), this second component represents accruals related to the pension asset/liability management business, unrelated to the sponsoring firm's core business. In general, current earnings (or costs) due to this non-operating component of total earnings should not afford the same value multiple as the firm's core operating earnings.

Figure 1 shows the annual flow of the financing accruals component, summed over our sample US firms with DB plans (left scale), alongside the marked-to-market value of DB plan net assets for these firms (right scale) Again, the accrual flows are embedded in the income statements while the net assets are merely disclosed in the footnotes. Beginning around 2001, the two measures give rather contradictory signals about the impact of the DB plan on the value of the sponsors' equity. When the stock market tumbled beginning in 2000 , what had been a large aggregate net pension asset became a net liability that persisted through 2005. By contrast, net pension accruals remained a sizable positive through 2002, only turning slightly negative in 2005. If investors were capitalizing, either implicitly or explicitly, the financing accruals in the income statement, rather than explicitly using the value of net pension assets reported in the footnotes, market equity values would not reflect the fair market value of the firm's DB plan. Figure 1 here

In previous work, Coronado and Sharpe (2003) have explored whether investors valued sponsors' DB pension exposures based on the fair market value of pension assets and obligations disclosed in footnotes or based upon pension financing accruals in their accounting earnings. That analysis focused on S\&P 500 firms over the years 1993-2001. They found that, although accounting expenses (or earnings) associated with pension plans could be a misleading measure 
of the underlying value of net pension obligations, the market seemed to focus on and price these accruals, rather than the pension balance sheet information revealed in the footnotes. Moreover, the valuation that the market placed on the pension-related accruals was indistinguishable from that placed on sponsors' core earnings. This implied that the stock prices of S\&P500 companies providing DB pension plans were generally misvalued over that period.

More recently, other authors have asked how pension accounting or pension shortfalls influence corporate valuation. For instance, Picconi (2006) examines how firms use pension assumptions to manipulate earnings and concludes that greater accounting clarity would help investors in the valuation process. Hann, Heflin, and Subramanyam (2006) find that the opaque approach to pension accounting embodied in FAS 87 is less value-relevant for bond investors than the transparent approach. Franzoni and Marin (2005) find that the stocks of firms with substantially underfunded pension plans earn negative abnormal returns over the next few years, suggesting that equity investors historically have shown a tendency to overvalue firms with underfunded pension plans. On the other hand, Jin et al. (2004) report that DB pension underfunding seems to be appropriately reflected in stock return volatility. In sum, controversy remains as to whether investors are fully aware of DB pension underfunding problems, and whether further transparency would benefit investors. ${ }^{8}$ In the next section we evaluate these questions directly.

\section{Recent and Prospective Accounting Reform}

Responding to the perception that DB plan pension accounting has been seriously deficient, the FASB is now reconsidering pension accounting standards as part of a broader

\footnotetext{
${ }^{8}$ There is some evidence that the change in methodology at the major rating agencies which now score unfunded pension liabilities as general obligation corporate debt, has been effective in bond markets, as bond prices now seem to appropriately reflect the parent firm's unfunded pension liabilities (Cardinale, 2005).
} 
effort to adopt more transparent, marked-to-market accounting standards across the board. To this end, in 2006, the FASB recommended that the pension accounting project proceed in two phases. Phase One resulted in Statement 158 and eliminated all smoothing of actuarial gains and losses in the funding position beginning in fiscal years ending after December 15, 2006. Expense calculations were not revised, and so reconciling entries were added to the "other comprehensive income" section of shareholder's equity. Phase Two, expected to take several years, will completely re-evaluate pension accounting including the expense calculations reported in the income statement. Given the FASB's goal of harmonizing US with international accounting standards, it is likely that FASB will aim to produce an accounting standard similar to the one used by the UK and continental Europe, where the only effect of the pension fund on the income statement results from the inclusion of service cost. Any other changes to the value of assets and liabilities that occur from market changes must be reflected on a marked-to-market basis on the balance sheet.

These two phases of the FASB's accounting reform will eventually result in the migration of key information from the footnotes to the balance sheet. They might also cause the removal of pension-related accruals from the main body of the income statement. Previous studies would suggest that this change in accounting will influence how the market values stocks of firms sponsoring DB pensions. Alternatively, the intense focus on pension accounting since 2000 and the widespread practice of plan underfunding may have already focused investors' attention on the issue sufficiently. In this case, investors may have been valuing pensions more accurately for some time and the new reporting standards will have little effect. Next we turn to an empirical analysis that should determine which of these outcomes is more likely. 


\section{Empirical Results: Have Financial Markets Caught On?}

To evaluate these alternative views, we employ the empirical valuation framework advanced by Feltham and Ohlson (1995), which is a parsimonious application of the residual income model. In the model, firm equity value $(P)$, is expressed as the sum of the value emanating from the firm's nonfinancial operating activities plus the value of unrelated financial activities. Our application of this model divides both the balance sheet and the income statement of the firm into components measuring the results from either (i) core operations or (ii) pension plan asset/liability management.

In particular, we measure core book equity value $(B V C)$ as total book equity value minus the book value of net pension assets, where the latter is defined in Compustat as prepaid pension cost (or minus accrued pension costs). Earnings from core operations (CoreEPS) is defined as total expected earnings minus pension earnings (EPS - PensionEPS), where pension EPS represents net financing accruals defined in Table 1 (net periodic pension cost minus service cost). Thus, the accrual of new pension obligations from current labor services (the service cost) is the only piece of pension cost treated as a core expense. Finally, the market value of pension assets minus the projected benefit obligation (PBO), which we call net pension assets, is denoted by NPA. Using this notation, we thus propose the following multivariate regression model:

$$
P_{t}=b_{0}+b_{1} B_{V} C_{t}+b_{2} \text { CoreEPS }_{t}+b_{3} N P A_{t}+b_{4} \text { PensionEPS }_{t}+u_{t}
$$

The transparent valuation model implies $0.65<b_{3}<1$ and $b_{4}=0$; that is, investors simply focus on the value of net pension assets rather than the associated flow of net financing accruals. ${ }^{9}$ The polar alternative, the opaque view of pension valuation, holds that investors value the stream of pension financing accruals reported in the income statement, that is, $b_{3}=0$ and $b_{4}>0$.

\footnotetext{
${ }^{9}$ A coefficient of 0.65 would imply valuation on an after-tax basis, where 0.65 is approximately equal to one minus the marginal tax rate faced by the corporate sponsor.
} 
In implementing this simple model, we introduce some minor modifications. First, to remove the time trend in the variables and the associated heteroskedasticity, all variables in (4) are normalized by assets (per share). Second, we control for more general earnings trajectories by adding a measure of analyst growth expectations (Growth Forecast). Finally, we include a Pension Indicator, a dummy variable that indicates whether the firm has a DB pension plan.

The two principal sources of data for our analysis are Compustat, for historical financial information including items related to company defined benefit pension plans, and $\mathrm{I} / \mathrm{B} / \mathrm{E} / \mathrm{S}$ International, for stock prices and analyst earnings forecasts. We focus on firms included in the S\&P 500 over the period 1993-2005. This yields a total of 7,290 firm-year observations; about two-thirds of these have DB plans. We begin our analysis in 1993 because many pension variables are unavailable in Compustat prior to that time. In addition, 1993-2005 is a particularly interesting period as it covers the boom, bust, and subsequent recovery of the equity market.

Estimation results appear in Table 2, with columns (1)-(4) covering what we call the 1993-2001 "pre-conscious" period, and columns (5)-(8) showing the analogous estimates for the more recent period, 2002-2005. During the latter period, we would expect investors to have paid particularly close attention to the value-relevance of DB pension plans, due to the dramatic swing from over- to under-funding of DB plans from 2000-2002 and the consequent public attention on accounting distortions. All regressions include semiannual time controls and, except when noted, a set of broad industry dummies. ${ }^{10}$ In each case, regressions are estimated using robust regression, which mutes the influence of outliers.

\section{Table 2 here}

We begin by testing the transparent view of pension valuation against the simple alternative that the firm's equity value fails to accurately reflect the value of net pension assets.

\footnotetext{
${ }^{10}$ The data appendix at the end of the paper describes the sample in more detail.
} 
As argued above, under the transparent view, the market value of the firm will fully reflect the value of net pension assets (or net liabilities) reported in the footnotes to the 10-K; for instance, the coefficient on Pension NAV in equation (1) should be between 0.65 and 1. Column (1) controls for the value of core operations, reflected in core book value and expected core earnings (Core EPS); but it excludes Pension EPS, the component of expected earnings associated with pension accruals. For the initial period we examine, the coefficient estimated on Pension NAV is 0.93 , which is highly significant and not significantly different from one, suggesting that the market did accurately price corporate pension assets and liabilities.

At the same time, core earnings were priced with a coefficient of 15.74 , implying that each dollar of expected core earnings added over 15 dollars to market price. As we would expect, core book value had a positive marginal effect (0.28) on market equity value. A higher analyst growth forecast also had a positive effect on the market value of equity: in particular, a 10 percentage point increase in expected long-term growth added three percentage points to the ratio of market equity value to book asset value. Finally, the coefficient on the pension indicator indicates that, all else equal, firms with DB plans had slightly higher market values on average (relative to assets), perhaps because the presence of a defined benefit plan was correlated with omitted firm characteristics such as firm age.

A more demanding test involves putting the transparent view up against a specific alternative, the opaque view, which presumes that the market instead values the pension financing accruals (expected return and interest cost) booked in accordance with FAS 87. In this test, we include Pension EPS as an additional regressor. One concern in running this test is that Pension EPS and Pension NAV might be highly correlated. Figure 1 demonstrated the disconnect between these two measures in the aggregate time series. Figure 2 graphs the cross- 
sectional correlation of the two measures by year. Clearly the two are not always closely related, so the test should be econometrically sound. The early-period estimates of this specification are shown in Column (2) where the transparent view is now strongly rejected: the coefficient on Pension NAV drops to 0.05, while the coefficient on Pension EPS is 13.89. Moreover, we cannot reject the restriction that the market valued pension accruals no differently than core earnings. ${ }^{11}$

The central question of this paper concerns whether the market correctly focused on the disclosed value of pension assets and liabilities after the huge stock market and interest rate swings around the turn of the decade, when market strategists and regulators focused attention on the shortcomings of pension accounting standards. The answer is given by Columns (5) and (6), where we have estimated the same models on the data for 2002-05. Surprisingly, here we reject the transparent view even using the less stringent test against the general alternative. The coefficient on Pension NAV in (5) is very small and insignificant. In the more stringent test, this coefficient even becomes negative though not statistically significant, while the coefficient on Pension EPS is 19.08 , larger than that on Core EPS. ${ }^{12}$ The other coefficients are mostly similar to those for the early period, though Pension Indicator is only marginally significant.

To test the robustness of these results, we re-estimate the valuation model using fixed effects, which focuses the analysis on explaining within-firm valuation differences across time. The advantage of such an approach is that it removes potential omitted variable biases; the disadvantage is that it requires our measures of expected earnings and pension value to be timely

\footnotetext{
${ }^{11}$ Viewed together, the results in columns (1) and (2) also provide a rationale for why our conclusions might differ from those of Jin et al. (2006). That study concluded that the market prices the pension plan risk correctly but this result is based on a test against a relatively weaker alternative hypothesis, similar to the test in column (1). If tested against a specific alternative, analogous to column (2), their conclusions might be reversed.

${ }^{12}$ When Pension NAV is dropped from the regression, this coefficient drops to 18.3 , which is not significantly different from that on core earnings.
} 
measures of the variables the market is focusing on at the time the stock price is measured. ${ }^{13}$ As shown in Column (3), the results are basically unchanged for the early period, though the coefficient on core earnings is a bit lower. For the later period, reported in Column (7), it again appears that the market prices pension accruals rather than pension NAV, though here the coefficient on pension accruals is significantly lower than the coefficient on core EPS.

Our final test provides ancillary support for our interpretation. We have argued that Pension EPS is a poor measure of the plan sponsor's true pension position (and cost) because smoothing delays the impact of recent plan performance on expense/earnings; in effect, Pension EPS reflects a three-to-five-year moving average of the plan's condition. If so, then lagged values of Pension NAV might have incremental explanatory power for sponsors' current stock price: the market prices stale information. We test this by adding to the first specification, from Columns (1) and (5), the twice-lagged value of Pension NAV, that is, the value from two years prior to the measure already included. Results appear in Columns (4) and (8). Consistent with our conjecture, the second lag comes in significantly. This is particularly notable in the later period where the twice-lagged measure has a coefficient of 0.89 despite the finding that more current measure had no explanatory power in the original specification.

\section{Implied Valuation Errors}

We conclude that market participants are not pricing the fair market value of pension assets and liabilities but instead appear to value pension earnings no differently than operating earnings. As a result, some firms with DB plans could be substantially misvalued. To get some bearing on the magnitude of the resulting valuation errors, we use a use a simple PE ratio model

\footnotetext{
${ }^{13}$ To reduce this potential problem somewhat, we eliminated firms for which there were fewer than three observations.
} 
of valuation, together with the assumption that Pension EPS is priced the same as Core EPS. Accordingly, we first estimate the value placed on each firm's earnings in each year by estimating a model of the PE multiple, which includes time and broad industry dummies, firm size, and two key "fundamental" determinants of PEs, the dividend payout rate and expected earnings growth. Regression results, together with standard errors, are:

$$
\ln \left(\frac{P_{t}}{E P S_{t}}\right)=0.17 * \ln \left(\text { div }_{t}\right)+0.57 * \ln \left(\text { growth }_{t}\right)-0.015 * \ln \left(\text { assets }_{t}\right)
$$

where EPS is (total) expected current-year earnings per share, div represents the current dividend payout rate, growth refers to the analysts' consensus long-term growth forecast, and assets is the total book value of firm assets, a proxy for firm size.

Given our finding that investors do not distinguish between operating and pension earnings, one can estimate the market's implicit value of the pension plan by multiplying the firm's Price-Earnings multiple by the Pension EPS. The resulting figure is an estimate of the incremental value to the firm's equity attributable to the market's valuation of pension accruals. To construct estimates of the valuation errors (on the stocks of pension plan sponsors), we subtract the pension net asset value reported in the footnotes (the fair market value of pension assets minus the $\mathrm{PBO}$ ). Figure 3 shows the resulting distribution of firm valuation errors as a percent of firm market capitalization from 1993-2005. Each vertical line represents the $10^{\text {th }}$ to $90^{\text {th }}$ percentile range for each year, and the diamonds indicate the median valuation error. Also shown are the weighted average valuation errors for each year, a measure of the aggregate impact on the market capitalization of S\&P 500 firms with DB plans.

\section{Figure 3 here}

The results clearly indicate the impact of investors failing to distinguish between pension 
accruals and net pension assets. The rise in the top end of the distribution by 2000 and 2001 illustrates the extent to which investors were overvaluing certain firms that continued to show large positive pension accruals during this period, even as their pension net asset values fell due to the market decline. In fact, during this period, model estimates suggest that some firms were as much as 20 percent overvalued, even though the aggregate effect on our sample was a five percent valuation error. Since 2002, firm valuation errors have fallen and become more evenly distributed around zero. Indeed, in the last couple of years, some firms were apparently undervalued because their pension accruals were highly negative from the lagged effects of the earlier market decline, despite the rebound in the reported value of net pension assets.

\section{Discussion and Conclusions}

There has long been an important disconnect between the financial impact of the pension plan implied by accounting accruals, and the information disclosed in the footnotes. Despite much attention from the accounting profession and Wall Street, our results suggest that investors still do not correctly perceive how DB pension plans influence corporate valuation in the US marketplace. As a result, over the past decade, pension accruals embedded in the financial statements have been particularly poor stand-ins for pension value. Indeed, pension accruals are potentially worse than noise, as there are times when they have been negatively correlated with the value of pension assets.

While the valuation errors we estimate are not large in the aggregate, they can be fairly sizable for individual companies. Since the disconnect between net asset values and pension accruals ought to error-correct over time, our results suggest that investors who do understand the oddities of pension accounting ought to be able craft a strategy to earn abnormal returns. 
Indeed, Franzoni and Marin (2006a, 2006b) find that, over roughly the same period as the one we study, investors would have been earned excess returns over three-five year holding periods by shorting firms after they report large pension deficits in their footnotes. This suggests that the second phase of FASB's reform efforts may have important consequences for the market values of firms sponsoring DB pensions. 


\section{References}

Black, Fischer. (1980). "The Tax Consequences of Long-Run Pension Policy.” Financial Analysts' Journal (July-August): 21-30.

Blitzer, David M., Robert E. Friedman, and Howard Silverblatt. (2001). "Measures of Corporate Earnings." Standard \& Poor's, New York, NY.

Bulow, Jeremy I., Robert Morck, and Lawrence Summers. (1987). "How does the Market Value Unfunded Pension Liabilities?" In Issues in Pension Economics, edited by Zvi Bodie, John B. Shoven and David A. Wise. University of Chicago Press.

Cardinale, Mirko. (2005). “Corporate Pension Funding and Credit Spreads.” Watson Wyatt Technical Paper.

Coronado, Julia and Steven A. Sharpe. (2003) Did Pension Plan Accounting Contribute to a Stock Market Bubble?" BPEA (1): 323-359.

Feldstein, Martin S. and Robert Morck. (1983). "Pension Funding Decisions, Interest Rate Assumptions, and Share Prices." In Financial Aspects of the United States Pension System, edited by Zvi Bodie and John B. Shoven. University of Chicago Press.

Feldstein, Martin S. and Stephanie Seligman. (1981). "Pension Funding, Share Prices and National Savings." Journal of Finance (September): 801-824.

Financial Accounting Standards Board. (1985). Statement of Financial Accounting Standards No. 87: Employers' Accounting for Pensions. FASB, Stamford, Ct. Dec.

Financial Accounting Standards Board. (2003). Statement of Financial Accounting Standards No. 132: Employers' Disclosures about Pensions and Other Postretirement benefits - an Amendment of FASB Statements No 87, 88, and 106. FASB, Stamford, Ct. Dec.

Feltham, G. and J. Ohlson (1995). "Valuation and Clean Surplus Accounting for Operating and Financial Activities." Contemporary Accounting Research 11(2): 689-732.

Financial Accounting Standards Board. (2006). Statement of Financial Accounting Standards No. 158: Employers' Accounting for Defined Benefit Pensions and Other Postretirement Plans - An Amendment of FASB Statements No 87, 88, 106, and 132. FASB, Stamford, Ct. Sept

Franzoni, Francesco and Jose Marin. (2006a). "Pension Plan Funding and Stock Market Efficiency," Journal of Finance (61): 921-956.

Franzoni, Francesco and Jose Marin. (2006b). "Portable Alphas from Pension Mispricing," Journal of Portfolio Management (Summer): 44-56.

Gold, Jeremy. (2005). “Accounting/Actuarial Bias Enables Equity Investment by Defined Benefit Pension Plans." North American Actuarial Journal. July: 1-25.

Hann, Rebecca, Frank Heflin, and K.R. Subramanyam. (2006). "Fair-value Pension Accounting." Working paper, USC.

Jin, Li, Robert C. Merton, and Zvi Bodie. (2004) "Do a Firm's Equity Returns Reflect the Risk of its Pension Plan?” NBER Working Paper No. W10650.

McGill, Dan M., Kyle N. Brown, John J. Haley, and Sylvester J. Schieber. (1996). 
Fundamentals of Private Pensions. Philadelphia, Pennsylvania: University of Pennsylvania Press.

Moran, M and A.J. Cohen. (2005) "Pension Accounting: FASB Finally Moving Forward." Goldman Sachs Group, Inc.

Picconi, Marc. (2006). "The Perils of Pensions: Does Pension Accounting Lead Investors and Analysts Astray?" Accounting Review 81(4): 925-955.

Sharpe, William F. (1976). "Corporate Pension Funding Policy.” Journal of Financial Economics 3(2): 183-193.

Tepper, Irwin. (1981). “Taxation and Corporate Pension Policy.” Journal of Finance 36(1): 113.

Zion, David and Bill Carcache. (2002).“The Magic of Pension Accounting." Credit Suisse First Boston. September. 


\section{Data Appendix}

The dataset used for this analysis includes all firms included in the S\&P 500 over the period 1993-2005; that is, we included all years for any firms in the index at any point over that time span. The resulting sample includes 7,290 firm-years, or an average of 561 data points per year. Companies with DB plans comprise $71 \%$ of the sample; firms without DB pension plans are $29 \%$ of our sample (nonDB companies are flagged with an indicator $(0,1)$ variable). Wharton Research Data Service (WRDS) made available to us the two data sources necessary, namely, Compustat for historical financial data, and I/B/E/S International for analyst forecasts and stock price data.

Variables from Compustat included firm financial data from 1993-2005, including book equity values, total assets, pretax income, and several variables related to the financial position of DB pension plans. Compustat data were then merged with earnings forecasts and pricing data from I/B/E/S using firm CUSIP numbers. Variables taken from I/B/E/S included annual observations of share price, shares outstanding, dividends per share, consensus (mean) forecasts of earning per share for both the current and subsequent fiscal years, and the median analyst forecast for long-term growth. The timing of the data match is chosen such that the date of pricing and forecast data follows the date of the financials reported in each firm's $10-\mathrm{K}$. This is intended to ensure that market and analyst forecasts incorporate reported financial data as of the measurement date. To do so, our sample is broken into two halves: firms with fiscal years ending in October through March are matched with price and forecast data from May of the subsequent year; and firms with fiscal years ending April through September are matched with price and forecast data from November of the same year. 
Table 1. Accounting Costs for DB Pension Plans

Item Definition

\begin{tabular}{lll}
\hline+ Service cost & Present value of benefits earned this year \\
+ Interest cost & $\begin{array}{l}\text { Interest cost on current benefit obligation } \\
\text { Amortization of gains, losses and prior } \\
\text { service cost } \\
\text { Amendments, actuarial assumption changes }\end{array}$ \\
+ Other costs & Assumed return on market-related value \\
& R*MRV (5-yr smoothing of unexpected R) \\
- Expected return on plan assets & On income statement \\
$=$ Net periodic pension cost (NPPC) & In "core EPS" \\
Service cost & Used for "Pension EPS" \\
\hline
\end{tabular}

Source: Adapted from Coronado and Sharpe (2003). 


\begin{tabular}{|c|c|c|c|c|c|c|c|c|}
\hline \multirow[b]{2}{*}{ Regressors } & \multicolumn{4}{|c|}{$\underline{1993-2001}$} & \multicolumn{4}{|c|}{$\underline{2002-2005}$} \\
\hline & (1) & (2) & (3) & (4) & (5) & $\underline{(6)}$ & (7) & $\underline{(8)}$ \\
\hline \multirow[t]{2}{*}{ Core EPS } & 15.74 & 15.71 & 10.49 & 18.03 & 15.81 & 15.57 & 11.39 & 15.91 \\
\hline & $(0.09)$ & $(0.09)$ & $(0.10)$ & $(0.12)$ & $(0.13)$ & $(0.13)$ & $(0.13)$ & $(0.13)$ \\
\hline \multirow[t]{2}{*}{ Pension EPS } & & 13.89 & 13.72 & & & 19.08 & 7.61 & \\
\hline & & $(1.98)$ & $(1.81)$ & & & $(2.22)$ & $(1.66)$ & \\
\hline \multirow[t]{2}{*}{ Pension NAV } & 0.93 & 0.05 & -0.04 & 0.44 & 0.03 & -0.29 & 0.13 & -0.41 \\
\hline & $(0.10)$ & $(0.16)$ & $(0.15)$ & $(0.19)$ & $(0.20)$ & $(0.20)$ & $(0.26)$ & $(0.22)$ \\
\hline \multirow[t]{2}{*}{ Core Book Value } & 0.28 & 0.30 & 0.61 & 0.19 & 0.40 & 0.44 & 0.25 & 0.38 \\
\hline & $(0.03)$ & $(0.03)$ & $(0.04)$ & $(0.04)$ & $(0.04)$ & $(0.04)$ & $(0.05)$ & $(0.04)$ \\
\hline \multirow[t]{2}{*}{ Growth Forecast } & 3.05 & 3.06 & 1.60 & 3.16 & 1.75 & 1.99 & 0.48 & 1.87 \\
\hline & $(0.08)$ & $(0.08)$ & $(0.10)$ & $(0.11)$ & $(0.13)$ & $(0.13)$ & $(0.11)$ & $(0.13)$ \\
\hline \multirow[t]{2}{*}{ Pension Indicator } & 0.05 & 0.04 & & 0.05 & -0.03 & -0.03 & & -0.02 \\
\hline & $(0.01)$ & $(0.01)$ & & $(0.02)$ & $(0.02)$ & $(0.18)$ & & $(0.02)$ \\
\hline \multirow[t]{2}{*}{ Pension NAV, lag 2} & & & & 0.54 & & & & 0.89 \\
\hline & & & & $(0.19)$ & & & & $(0.20)$ \\
\hline N (obs.) & 5,275 & 5,275 & 5,274 & 3,925 & 2,015 & 2,015 & 1,951 & 1,977 \\
\hline Root MSE & 0.318 & 0.315 & 0.204 & 0.359 & 0.297 & 0.287 & 0.116 & 0.292 \\
\hline Measure of fit (adj- $\left.R^{2}\right)$ & 0.933 & 0.934 & & & 0.922 & 0.925 & & 0.924 \\
\hline
\end{tabular}

Notes: Dependent Variable is Market Equity value normalized by Book Assets. All regressors except for the Growth Forecast and Pension Indicator are also normalized by Book Assets. Regressions also include time and broad industry controls. Standard errors appear below coefficient estimates.

Source: Authors' calculations. 
Figure 1

Pension Net Asset Value versus Financing Accruals

( $\$$ billions)

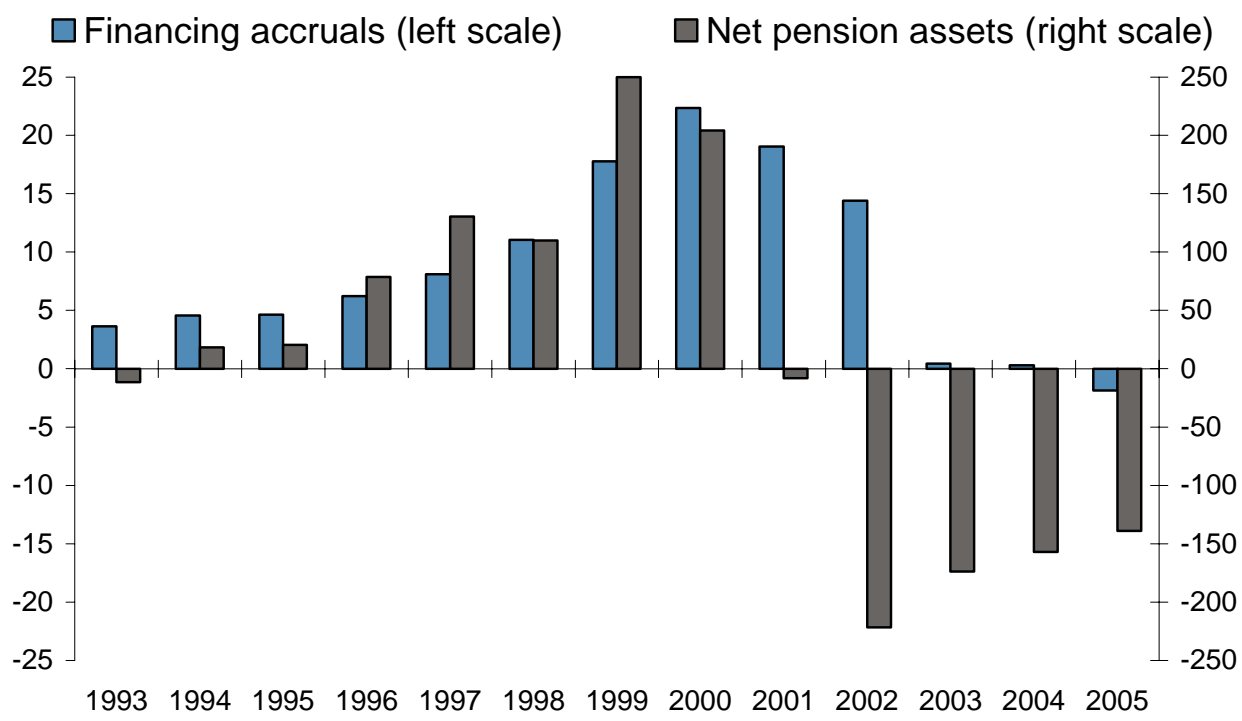

Source: Compustat and authors' calculations; see the Data Appendix.

Figure 2

Cross-Sectional Correlation of Pension EPS with NAV

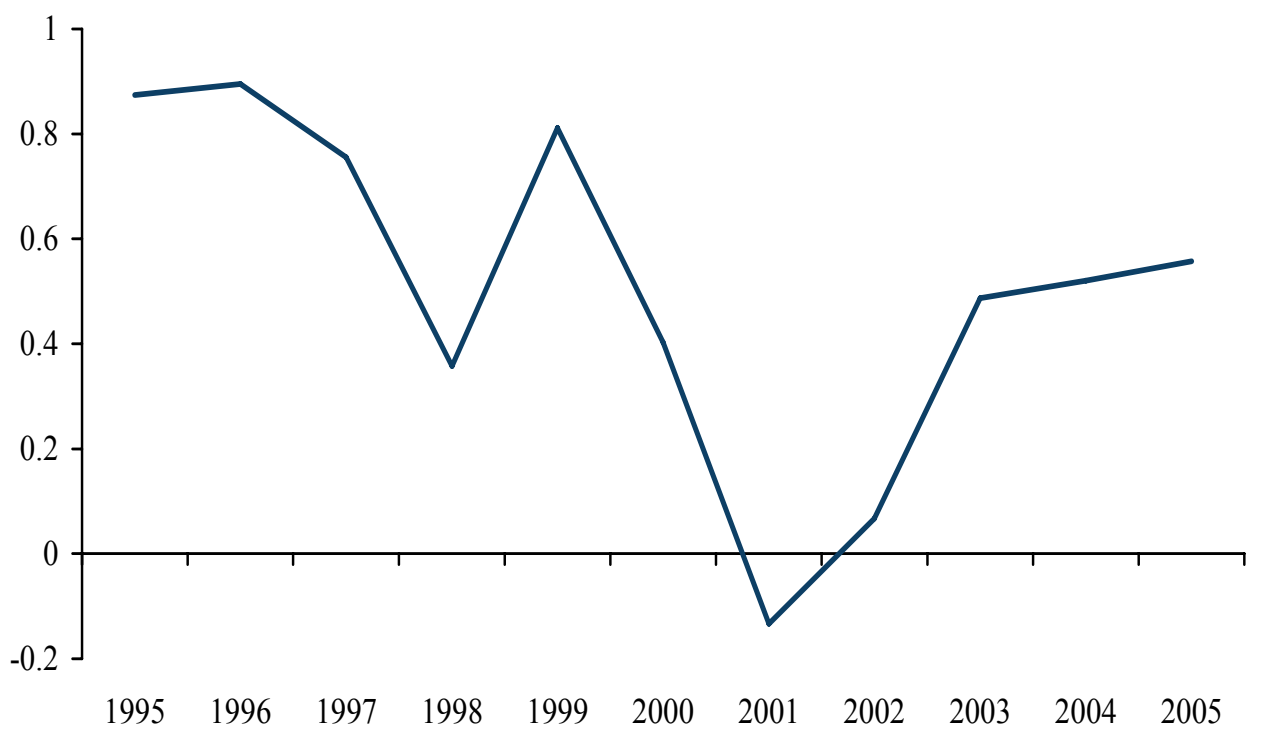

Source: Compustat and authors' calculations; see the Data Appendix. 


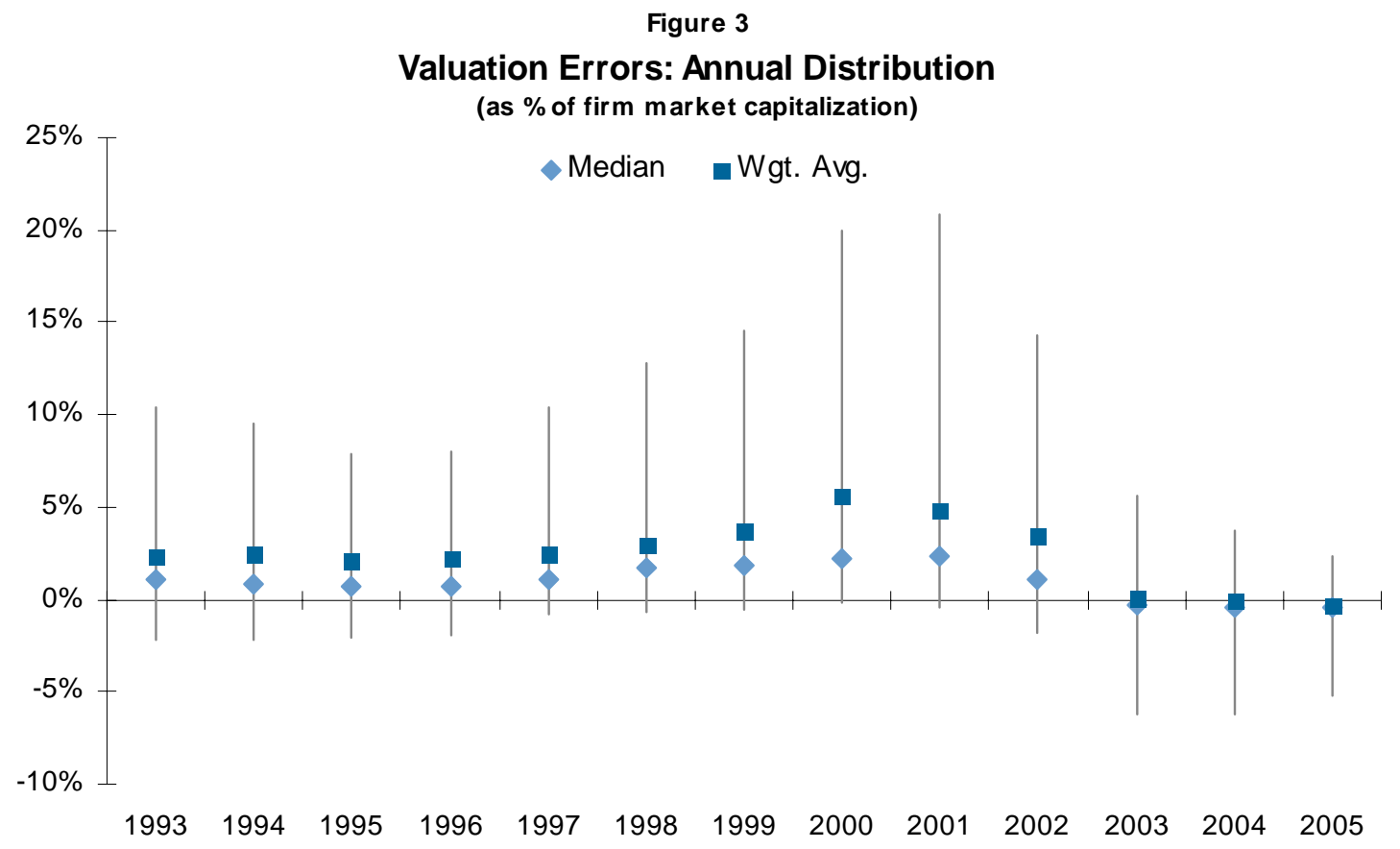

Source: Compustat, IBES, and authors' calculations; see the Data Appendix. 